\title{
The deindustrialization/tertiarization hypothesis reconsidered: A subsystem application to the OECD7
}

\begin{abstract}
The diffusion of outsourcing and vertical FDI among manufacturing firms, along with the vertical integration of market services into manufacturing, is questioning the so called 'Deindustrialization/Tertiarization (DT) hypothesis'. In particular, it has been argued that DT might be an 'apparent' phenomenon, in fact amounting to a simple reorganization of production across national and sectoral boundaries. The empirical studies that try to support this hypothesis, however, cannot be deemed conclusive as they suffer two methodological drawbacks: a non-(sub-)systemic sectoral level of analysis and a not truly global empirical approach. In order to overcome these drawbacks, the paper carries out an investigation of the actual extent to which DT occurred in the OECD area over the 1980s and the 1990s with two modifications: a sector instead of a subsystem perspective, retaining both direct and indirect relations; a 'pseudo-world' of seven OECD countries, thus taking into account the 'global' dimension of the phenomenon. Our results strongly support the DT hypothesis: although the weight of market services in the manufacturing subsystem increases, providing a counterbalance to manufacturing decline, subsystem shares significantly decrease, thus confirming DT as a more fundamental trend of the investigated period.
\end{abstract}

Keywords: Deindustrialization; Input-output; Producer services; Tertiarization; Subsystem; Vertical integration.

JEL Classification: L600; L800; O140; P000. 


\section{Introduction}

Although it dates back to the early 1940s, the hypothesis that economic development passes through a binomial DeindustrializationTertiarization (DT) has reemerged in recent debate. ${ }^{1}$ Despite the use of buzzwords, such as 'new-economy', 'knowledge-economy', 'learningeconomy', and the like (Foray, 2000), the current techno-economic paradigm appears incontrovertibly service-oriented. Some consider this feature of modern economies the only one that might be properly regarded as 'new' (e.g. Daniels, 2004). Not only is the service sector of Information and Communication Technologies (ICT) pivotal in driving modern economic activity and performances (Di Pilat, 2003), but services, both generally and in particular fields - such as the so called Knowledge Intensive Business Services (KIBS) (Tomlinson, 2000) are re-shaping economic fundamentals, from the demand and supply sides. $^{2}$

Although the impact of DT seems to have become nowadays even more important, however, the results of empirical applications to quantify and evaluate these processes are far from conclusive (e.g. McCarthy and Anagnostou, 2004; Dietrich, 1999). Apparently, rather than emerging as more deindustrialized and tertiarized, modern developed economies in these studies seem to be specialized in more kinds of services, or differently organized in terms of the relationship between manufacturing and services. The so-called Clark-Fisher hypothesis, which assumes that economic development is characterized by a shift from agriculture to manufacturing and from manufacturing to services, thus would not fit with the new-economy paradigm.

The present paper aims at addressing the actual extent of this hypothesis, that is, at establishing whether the last decades have been characterized by an actual DT process. Whether or not the DT is due to a change in the productivity of the manufacturing and services sectors the famous 'Baumol disease' (Baumol, 1967) - is not directly relevant

1 This is usually referred to as the Clark-Fisher hypothesis. Clark (1940) refers to 'Petty's Law' and, relying on a passage from Political Arithmetick (1676), credits Petty with having first suggested it.

2 In terms of the demand side, Sherwood (1994), for instance, claims that services in the 'new economy' have highlighted the role of the consumer, given his/her active involvement in service provision. For the supply-side, Andersen and Corley (2002), among others, point out that standard measures of productivity and economic performance are no longer satisfactory, given their inadequacy for measuring productivity and output in services. 
to this study, which is not concerned with causes of DT, only its extent. We would claim that those empirical studies that show the 'impure' nature of DT, which are reviewed in Section 2, are affected by a crucial methodological flaw. In brief, since they are based on sectoral data, they do not take into account indirect effects, thus miscalculating the 'total' shares of employment and the value created in the production of manufactured goods or the provision of services to satisfy final demand. Furthermore, sector-based approaches to DT rely on theoretical hypotheses about the organization of production that are not fully consistent with those in spatial and temporal contexts.

Thus, in Section 3, we adopt the subsystem approach developed originally by Momigliano and Siniscalco (1982a, 1982b) as a superior alternative for the investigation of structural change in modern developed economies.

A major value added of this paper is that this subsystem approach is applied to investigate the extent to which DT processes occurred in the 1980s and 1990s, in an 'artificial' world, using aggregated data for seven OECD countries - Canada, Denmark, Germany, France, Japan, UK and USA (the OECD7) - which together account for almost half of world GDP at Purchasing Power Parity (PPP). The special features of this empirical application, illustrated in Section 4, allow us to identify the multiple mechanisms that have underpinned structural change in these developed countries from the 1980s to the 1990s.

We argue in Section 5 that, although the weight of market services in manufacturing subsystems has increased, counterbalancing manufacturing decline, shares of labour and value added of manufacturing have decreased considerably. This appears even more marked than in sectoral investigations, and cannot be explained by the increasing resort of the OECD7 to international trade. Moreover, this decline cannot be accounted for by the increased integration of manufacturing in service subsystems which, possibly due to diffusion of ICT, has paralleled the increased integration of services into manufacturing.

Section 6 summarizes the main points of the paper and draws some conclusions.

\section{The DT hypothesis: old and new evidence}

Since Clark's (1940) major contribution, deindustrialization - defined as the decline in manufacturing shares of both employment and value 
added in economic systems - has been regarded as a general tendency in economic development, and as strictly connected to tertiarization, that is, the increased share of the 'tertiary' or services sector.

This tendency has been related to both demand and supply-side factors, with economists pointing to higher income elasticities and slower pace of productivity increase in services with respect to manufacturing. Which of these factors dominates has not been ascertained yet. $^{3}$

Both the determinants of DT and its actual extent are still subject to empirical investigation, so that DT is often considered a hypothesis. And Clark (1957), some 17 years after having suggested it, was still questioning it, as can be seen from the third edition of The Conditions of Economic Progress, in which he observes that most of the results for the tertiary sector held only if services were subdivided into producer and consumer activities - a distinction that became crucial in downplaying the actual extent of DT (Greenfield, 1966; Stanback, 1979, 1981).

Critical arguments about the occurrence of DT were proposed through comparisons with the idea of a self-service economy (Gershuny, 1978) ${ }^{4}$ and other kinds of structural change related to the consolidation of smaller firms into larger units, government regulation of the economy and the widespread diffusion of service outsourcing practices (Stanback, 1979).

Service outsourcing has drawn attention on the integration of services in manufacturing, and the related possible overestimation of the actual decline (increase) in manufacturing (services). This point, first proposed by Momigliano and Siniscalco (1982a, 1982b) with

3 In addressing the productivity slowdown in the US, the classic book by Baumol et al. (1989) places the shift from a manufacturing to a service economy among those factors that bring about changes in productivity. In accounting for this shift, some claim that demand-side factors are the most prominent (e.g. Clark, 1940; Rostow, 1959, 1990; Pasinetti, 1993), while others play down the role of demand and highlight supply-side factors as critical (e.g. Stigler, 1956; Kuznets, 1957; Fuchs, 1964, 1965; Baumol, 1967). Rowthorn and Ramaswamy (1997, 1999) find evidence to support this latter view. This question is still debated, but not directly relevant to the objective in this paper.

4 This self-service economy was characterized, on the one hand, by an increased number of domestic durable goods purchased by households that eliminate their dependence on outside services; on the other hand, by increased industrial production requiring an extended service support sector (e.g. advertising, marketing, financial and insurance services). 
respect to the Italian economy, has been addressed and confirmed in a number of larger scale empirical studies (e.g. Domberger, 1998; Dietrich, 1999; McCarthy and Anagnostou, 2004), which have thus contradicted the DT hypothesis.

This hypothesis becomes even less clear cut if we consider the increasing resort to international trade and the upsurge in the international fragmentation of production. ${ }^{5}$ Although the latter apparently fuels DT, delocalization of manufacturing processes abroad and localization of service based activities at home does not fully account for it, because it involves a simple reorganization of production across national boundaries, but no change in terms of the overall economic structure. ${ }^{6}$

The shift in production and especially employment towards services has become a hot topic in the economics of structural change: two of the most notable journals in the field - Metroeconomica and Structural Change and Economic Dynamics - have recently dedicated review articles and Special Issues to this subject (e.g. Schettkat and Yocarini, 2006; Schettkat, 2007).

The conclusion of a recent study (Schettkat and Yocarini, 2006, p. 127 ) is quite illuminating: 'The shift to services is not just a price effect nor is it mainly the effect of the outsourcing of service activities from manufacturing industries. The shift to services is real'. This needs confirmation with more empirical evidence and a robust methodology to test the DT hypothesis, the objective of the present paper.

\section{The DT hypothesis reconsidered: from a sector to a subsystem perspective}

Although it provides some useful insights, the empirical evidence on an 'apparent' DT hypothesis suffers from a crucial methodological

5 On the impact of trade specialization in manufacturing/services on the employment structure of one economy (in that case, the UK since the Second World War ) see Rowthorn and Wells (1987). On the international fragmentation of production see, among the others, Jones and Kierzkowski (1990).

6 Following these lines of argument, some economists have concluded that much of the observed surge in producer services could be a "superficially different way for business to operate and can be reasonably explained within the economic literature on industrial organization. An extreme version of the argument claims that no new producer services employment, particularly business services employment, have really been created in recent years" (Postner, 1990, p.178). 
limitation. As noted by Momigliano and Siniscalco (1982a, 1982b), in all such work 'producer services are defined as those services mainly intended for intermediate demand, and consumer services as those mainly intended for final consumption' (Momigliano and Siniscalco, $1982 \mathrm{a}$, p. 276 , emphasis in original). In those studies, the economy is disaggregated into sectors - usually based on standard SIC definitions - by assuming that demand, output and technology within each sector are homogeneous, and can be studied in 'relative isolation from the rest' (Georgescu-Roegen, 1971).

This hypothesis has two implications for the analysis of DT. Firstly, it amounts to assuming that intra-sectoral relationships are stronger than intersectoral ones. In other words, sectors are dealt with as though they were vertically integrated models of production: the intermediate inputs of a certain sector are not regarded as means of production, but rather as products external to the sector, in which the sector does not play a role - either directly or indirectly - which is not the case (on this point see Baranzini and Scazzieri, 1990). Secondly, the sectoral view of the economy is extremely sensitive to changes in the way firms within sectors actually organize the production process, which could be understood - erroneously - as structural change. Thus, for instance, if some business activities previously performed 'in house' by manufacturing companies are simply re-organized, and outsourced to specialist subcontractors, all things being equal, this will increase the share of the service sector and produce a decrease in manufacturing, suggesting an 'apparent' tertiarization.

While possibly not so crucial in past techno-economic paradigms, these two implications seriously hamper the analysis of DT in the present scenario. On the one hand, in the so-called 'knowledgeeconomy', the wide spread of ICTs, by allowing for more extended network relationships, has increased the relative importance of horizontal as opposed to vertical linkages among sectors. On the other hand, the increasing use of outsourcing has dramatically changed the actual organization of production, at least in the OECD area (e.g. Domberger, 1998).

In trying to overcome these limitations and to measure the real weight of manufacturing vs services in the economic system, we suggest a different perspective and refer explicitly to the idea of economic vertical integration. ${ }^{7}$ This was first proposed by Momigliano

7 The origins of vertical integration go back to William Petty (1662) and Adam 
and Siniscalco (1982a, 1982b) for their investigation of structural change in the Italian economy from the mid 1960s to the mid 1970s. More precisely, in order to detect the actual degree of the Italian tertiarization process in light of service integration in manufacturing, Momigliano and Siniscalco refer to the concept of a subsystem by constructing a matrix:

$$
\mathbf{B}=\hat{\mathbf{q}}^{-1}(\mathbf{I}-\mathbf{A})^{-1} \hat{\mathbf{y}}
$$

where $\hat{\mathbf{q}}$ is the diagonalized vector of gross production, $\mathbf{A}$ is the matrix of domestic flow-based input-output coefficients and $\hat{\mathbf{y}}$ is the diagonalized vector of final demand.

Each row of $\mathbf{B}$ adds up to 1 and shows 'the proportion of the activity of each branch which comes under the various subsystems' (Momigliano and Siniscalco, 1982a, p. 281). ${ }^{8}$ B therefore can be used as an operator to reclassify any variable from a sector base into a subsystem base. On the basis of B, Momigliano and Siniscalco (1982a, $1982 b$ ) actually worked out the matrix $\mathbf{N}$, which is crucial for an investigation of DT processes from a subsystem perspective, and is defined as:

$$
\mathbf{N}=\hat{\mathbf{l B}}
$$

where $\hat{\mathbf{i}}$ is the diagonalized vector of labour inputs. The generic element $n_{i j}$ of $\mathbf{N}$ is the amount of labour required, both directly and indirectly, from sector $i$ in order to satisfy the final demand in sector $j$.

Also of relevance is the matrix $\mathbf{C}$, which is obtained dividing each of the cells in $\mathbf{N}$ by the total of the corresponding column. Denoting with i' a row unit vector, $\mathbf{C}$ can be written as:

Smith (1776), who extensively, though somewhat implicitly, used this 'logical device' (Scazzieri, 1990, p. 20). However, starting from the seminal notion of subsystem put forward by Sraffa (1960), it was not until the late 1960s that the concept of vertical integration was analytically studied by many, including Pasinetti (1973), who developed the concept of vertically integrated sector, a compact representation of the productive system suitable for dynamic analyses. Since then, these tools have been utilized mainly in empirical studies on productivity, e.g. Gossling (1972), Gupta and Steedman (1971), Wolff (1985), Milberg (1991), Panethimitakis (1993) and De Juan and Febrero (2000).

8 As noted by Rampa (1982), given that B depends on both strict technological factors and the structure of final demand, it cannot be taken as an indicator of technological change. 


$$
\mathbf{C}=\mathbf{N}\left(\widehat{\mathbf{i}^{\prime} \mathbf{N}}\right)^{-1}
$$

The generic element of $\mathbf{C}, c_{i j}$, measures the share accounted for by sector $i$ in total labour required by subsystem $j$ in order to satisfy final demand. It should be noted that, as demonstrated by Rampa (1982), all previous matrices are invariant to relative prices. ${ }^{9}$ A comparative analysis of the changes that occur over time in the above defined matrices is useful for disentangling the determinants of structural change. Indeed, while $\mathbf{N}$ works out levels, $\mathbf{B}$ and $\mathbf{C}$ measure shares and do not depend on, respectively, sectoral labour productivities and the final demand structure. More precisely, B calculates the shares of each subsystem in each relevant sector, for example in terms of total hours worked. Thus, changes in total employment in a certain sector, with gross production constant, do not affect these shares. On the other hand, assuming constant returns to scale, $\mathbf{C}$ is not affected by changes in the composition of final demand. And the same might hold if all sectors share the same patterns of returns to scale, either increasing or decreasing. If this is not the case and, for example, returns to scale are increasing in the manufacturing sectors only, an increase in industrial demand might lead to a decrease in the manufacturing elements of $\mathbf{C}$ (on this point see, Montresor and Vittucci, 2007).

To sum up, changes in $\mathbf{B}$ are mainly related to non proportional dynamics of final demand, whereas changes in $\mathbf{C}$ are a response to variations in sectoral labour productivity.

In what follows, we apply these and other indicators of subsystems in an original empirical investigation of the DT hypothesis in the OECD7 for the 1980s and 1990s. We next present the methodology.

9 Denoting with $\overline{\mathbf{x}}$ each magnitude $\mathbf{x}$ expressed in physical quantities and with $\hat{\mathbf{p}}$ the diagonalized vector of prices, we can write:

$$
\begin{aligned}
\mathbf{B} & =\hat{\mathbf{q}}^{-1}(\mathbf{I}-\mathbf{A})^{-1} \hat{\mathbf{y}}= \\
& =\left(\hat{\mathbf{q}}^{-1} \hat{\mathbf{p}}^{-1}\right)\left(\mathbf{I}-\hat{\mathbf{p}} \overline{\mathbf{A}} \hat{\mathbf{p}}^{-1}\right)^{-1}(\hat{\mathbf{p}} \hat{\mathbf{y}})= \\
& =\left(\hat{\mathbf{q}}^{-1} \hat{\mathbf{p}}^{-1}\right)\left(\hat{\mathbf{p}}(\mathbf{I}-\overline{\mathbf{A}})^{-1} \hat{\mathbf{p}}^{-1}\right)(\hat{\mathbf{p}} \hat{\mathbf{y}})= \\
& =\hat{\mathbf{q}}^{-1}(\mathbf{I}-\overline{\mathbf{A}})^{-1} \hat{\mathbf{y}}^{-1}
\end{aligned}
$$

It should be noticed that, by referring to a change in relative prices at constant output, the invariance in the previous equation does not require, per se, an assumption about returns to scale. 


\section{DT hypothesis in the OECD7: an 'aggregated' sector/subsystem analysis}

Our empirical application has several original elements. First, rather than focusing on each country separately, or on some countries comparatively, we attempt to estimate the extent of the DT hypothesis at the aggregate level: that is, by considering economic sectors and subsystems in a 'pseudo-world', consisting of seven countries (see Figure 1).

Insert Figure 1 about here

Although the choice of the countries was determined mainly by data availability, these seven economies are fairly well integrated at the international level: average international flows among the OECD7 in the period studied here amounted to some $45 \%$ of the total (Table 1). Accordingly, while it (deliberately) ignores some country specificities, the present analysis enables some appreciation of the extent to which DT processes occurred on a (pseudo) global scale: in an era of globalization, this would seem to be the appropriate level of investigation.

\section{Insert Table 1 about here}

A second original element, at least as far as an input-output data based applications are concerned, is the time span: which is early 1980s to the mid 1990s. This time span was chosen to fit with international trade data for our self-contained 'pseudo-world'. Extending the analysis beyond the $1990 \mathrm{~s}$, would have required the inclusion of new emerging countries (e.g. Brazil, Russia, India and China) for which OECD consistent input-output tables are not available. Accordingly, our results are historically specific rather than general.

By crossing two waves of the OECD Input-Output Database (1995, 2005), and combining them consistently with data on sectoral hours worked - obtained from the 60-Industry Groningen Growth and Development Centre Database (2005) - we can examine structural 
changes in the OECD7 provoked by the emergence of the knowledgebased economy.

A third novelty of our study is that the analysis considers domestic intersectoral flows as the baseline, but controls for changes in international trade along with degree of vertical integration at subsystem level. In particular, we use data on imports and exports of manufactured goods - from the OECD STAN Database (2004) - and country GDP at current prices - from the World Economic Outlook Database (2005) - to calculate the trade balance of manufactured goods as a percentage of country GDP, from 1980 to 1998.

This multiple and consistent integration of datasets to check for alternative explanations of DT is the fourth added value of the present application.

For each of the seven countries, the matrix $\mathbf{N}$ (Equation (2)), based on labour inputs, has been worked out for four periods: early 1980s, mid-1980s, early 1990s and mid-1990s. ${ }^{10}$ The data are aggregated in order to obtain six different macro-sectors and six corresponding subsystems: primary (1-14 ISIC Rev.3), manufacturing (15-37), public utilities (40-41), construction (45), market services (50-74) and nonmarket services (75-99). Finally, absolute values of $\mathbf{N}$ are summed across countries to obtain the corresponding values for the whole set, that is for the OECD7. ${ }^{11}$

In order to analyse the process of value creation at subsystem level, we follow a similar procedure for the sectoral value-added data (v). The $\mathbf{B}$ operators at country level are multiplied by the corresponding diagonalized vectors $(\hat{\mathbf{v}})$ :

$$
\mathbf{U}=\hat{\mathbf{v}} \mathbf{B}
$$

10 To try to avoid distortions due to sectoral aggregation, calculations are made at the maximum level of disaggregation compatible with country level data, and the results then re-aggregated. For details on the definition of the four periods see Appendix.

11 Note that this aggregation is possible given that data on labour inputs refer to homogeneous variables such as hours worked. Furthermore, given the research question investigated in this paper, i.e. determining the actual relative weight of services with respect to manufacturing, hours worked are aggregated without qualitative weighting in terms of skill levels for instance. Whether decline in manufacturing is a matter of relocation of resources from productive to unproductive uses - i.e. Baumol's disease - is not examined here. Rather we investigate whether a decline in manufacturing can be ascertained, regardless of its determinants. 
The generic element $u_{i j}$ of $\mathbf{U}$ gives the contribution of sector $i$ to subsystem $j$ in terms of value added.

Given that we are dealing with values, in order to obtain the aggregate matrix corresponding to the OECD7, in this case, we cannot simply sum the results for the different countries. Therefore, using data from the World Economic Outlook Database (2005), country shares have been weighted using PPP. Thus, we denote the share of sector (or subsystem) $j$ as $s_{j}^{c}$, with respect to the total value added of country $c$, and GDP based on Purchasing-Power-Parity (PPP) of the same country as $Y_{P P P}^{c}$; this means that the corresponding share for the set of the $\operatorname{OECD} 7\left(s_{j}^{O E C D}\right)$ is:

$$
s_{j}^{O E C D}=\sum_{c} s_{j}^{c} \frac{Y_{P P P}^{c}}{\sum_{c} Y_{P P P}^{c}}
$$

\section{The OECD7 from 1980 to the mid 1990s: 'DT or not DT'?}

\subsection{Has the OECD7 become more deindustrialized?}

At first sight, it would seem that in the period from the early 1980s to the mid 1990s, the OECD7 experienced a sustained DT process. When we consider both direct and indirect effects at subsystem level, the decline in manufacturing appears even steeper. Although the sectoral and subsystem analyses show the same general trends, the magnitude of the changes differ. ${ }^{12}$

\section{Insert Table 2 about here}

In terms of total hours worked, the share of the OECD7 manufacturing subsystem in the retained period decreased by 6.82 percentage points,

12 In Table 2 , in only 4 out of 18 observations the signs of change are different. Note also that changes at subsystem level will not necessarily be larger than those at sectoral level. The indirect effects captured by the former may outweigh the direct effects in the latter. 
while, during the same period, the sectoral share of manufacturing decreased by only 4.61 points (Table 3 ).

Insert Table 3 about here

The results for value added are similar in that the manufacturing subsystem shifted from a share of $29.57 \%$ of the total value created in the early 1980 s, to a share of $22.86 \%$ in the mid $1990 \mathrm{~s}$ : a decrease of 6.71 percentage points vs 4.58 points for the sectoral system (Table 4).

Insert Table 4 about here

For hours worked, there is a decline in relative and absolute terms: total hours worked for the OECD7 from the early 1980s to the mid 1990s increased continuously, while hours worked in manufacturing decreased (Table 2).

This is the first important result. If we take account of both horizontal and vertical linkages, the (pseudo-)world appears to have been affected by an actual deindustrialization process, in terms of both employment and value added. A purely sectoral approach, seems to hide much of this process, which is revealed within a subsystem perspective.

To conclude, it would be interesting to know whether our results for this 'pseudo-world' relate to all of the countries in the group, or are affected by some extreme cases in the OECD7, for example the US. Figure 2 suggests that the share of total hours worked in manufacturing is decreasing in all seven countries and this decrease is more pronounced at subsystem (Figure $2 \mathrm{~b}$ ) than sectoral level (Figure 2a), as in our 'pseudo-world'. The results are similar for share of value added (results available from the authors at request).

Insert Figure 2(a) and (b) around here

While this result was perhaps expected, we need to interpret the deindustrialization process identified, and especially the weight of the true tertiarization process. We present three possible interpretations in addition to the explanation of tertiarization. First, we clarify a methodological premise: the interpretation of the observed 
deindustrialization process is not addressed in causality terms, since the direction might be the reverse of what we expect. Also, the transmission channel of such a causal link is not the focus of this paper. Within a type of accounting exercise for the deindustrialization process, rather than investigating its causes, we attempt to decompose deindustrialization into possible explanations and establish their relevance.

\subsection{Deindustrialization and producer services: how much do they matter?}

In Section 2 we showed that there are more contributions that contrast the deindustrialization process with an increase in the role of producer services and, on this basis, question the decrease in the weight of manufacturing in modern developed economies. Our analysis does not entirely support this point of view. Although an increase in the share of market services in the manufacturing subsystem is confirmed by our data - in terms of both employment (Table 5) and value added (Table 6 ) - the decline of the manufacturing sector seems to be related only partially to this.

\section{Insert Tables 5 and 6 about here}

Consider the case of the OECD7 from the early to mid 1980s in terms of hours worked. While hours worked in the manufacturing sector decreased by $1,451,119$, the subsystem shows an increase of 9,470 hours worked (Table 2). This mismatch can be explained in part by the consistent increase $(+1,315,548$ hours worked) in the integration of market services into manufacturing (Table 5(a)). However, the share of the manufacturing subsystem in the total economy still decreased (0.96 percentage points) (Table 3 ).

We can find other mismatches for other periods, and also within individual countries in the OECD $7 .{ }^{13}$

Some of the differences in the patterns of change in the manufacturing sector and the corresponding subsystem might be due to producer services. However, from an accounting point of view, the

13 In the US, this also applies to the mid 1990s. The relevant tables are not presented here for reasons of space, but are available from the authors on request. 
tendency towards decline in manufactured goods production seems to be more fundamental. In other words, the decrease in manufacturing might have been even greater without the higher integration of market services, although the effect of this does not seem to have been enough to counteract the decrease. Section 5.5 shows that services are becoming larger users of market services, so that the considerable growth in this latter category is not linked exclusively to manufacturing activities.

\subsection{Is manufacturing more integrated at subsystem level?}

A different 'impure' (i.e. non tertiary related) interpretation of the observed deindustrialization, as Section 2 showed, is related to the structural change brought by the diffusion of ICT. This questions the deindustrialization hypothesis, but in terms of the changing nature of manufacturing being increasingly more focused on the hardware involved in the delivery of ICT. This recent wave of technological progress has resulted in intensive use of manufactured goods for the provision of services (both market and non-market), which should suggest, ceteris paribus, an increase in the share of the manufacturing sector in other subsystems, and the service subsystem in particular, in terms of both labour and value added. ${ }^{14}$

However, this is not fully confirmed by the OECD7. Rather, the percentage share of manufacturing in the market and non-market service subsystems does not show a regular increase over time. It shows a marked decrease from the early 1980 s to the early 1990 s,

14 Note that, given that manufactured goods related to ICT are mainly durable goods, and that input-output data do not include depreciation of fixed capital goods among intersectoral flows, referring to the subsystem level could underestimate the integration of manufacturing in services as well as the overall share of the manufacturing subsystem. However, following SNA93 accounting standards, in most of the countries in our sample, software related expenditures are included in investments. Therefore, if depreciation of capital goods is excluded, the integration of establishments providing such services in manufacturing is also underestimated. Which of the two subsystems is the more undervalued is difficult to establish. However, as the percentage of the total costs of software has progressively increased with respect to hardware costs since the 1960s, the market service subsystem is likely to have been underestimated more than the manufacturing subsystem. 
followed by a moderate increase in only a few cases (e.g. market services) (Tables 7(c) and 8(b)).

\section{Insert Tables 7 and 8 about here}

This decrease is not negligible: it was 1.17 percentage points in terms of hours worked and 1.22 percentage points in terms of value added, for the overall services subsystem. It is interesting that this decrease occurred in the presence of an actual increase in the integration of manufacturing in service subsystems, which supports the ICT hypothesis. This increase was fairly consistent in the first half of the 1990s: indeed, from the early to mid 1990s, the percentage of produced manufactured goods entering, directly and indirectly, into the provision of services, both market and non-market, increased by 3 percentage points in terms of hours worked, and 3.4 points in terms of value added (Tables 7(b) and $8(\mathrm{a})) .{ }^{15}$ As a consequence of this increased integration, in the mid 1990s these shares were, respectively, $15.1 \%$ (Table $7(\mathrm{~b})$ ) and $15.77 \%$ (Table $8(\mathrm{a})$ ), representing respectively, $2.73 \%$ of total hours worked and $1.97 \%$ of total value added for the OECD7. However, an actual deindustrialization should have also occurred, given that, despite the presence of increased integration, the weight of manufacturing in service subsystems has actually decreased.

Thus, although the diffusion of ICTs, along with other phenomena, can be related to the observed increase in the integration of manufacturing in services, and this integration might have had important consequences for the productivity growth of the latter, its impact in terms of labour and value added does not seem to have been sufficient to prevent an actual deindustrialization process.

\subsection{International trade}

A last 'impure' interpretation of the observed deindustrialization of the OECD7 can be found in the change in the sectoral composition of

15 Note that the increase in manufacturing integration in market services over the period was particularly marked in the USA due to the explosion in ICT. Indeed, from the early 1980s to the mid 1990s, the share accounted for by the market service subsystem in the manufacturing sector in terms of hours worked, increased from $7.59 \%$, a value already above the OECD7 average $(7.02 \%)$ to $11.35 \%$, the value for the OECD7 being $9.11 \%$ (Table 7(b)); value added increased similarly. Data for the US are available from the authors on request. 
trade-flows with respect to other economies. It could be that, based on the internal production flows presented in the input-output tables, the decline in the weight of internal manufacturing might have been counteracted by the increase in imports of foreign manufactured goods in the OECD7, especially in light of their increasing use of offshoring (Spencer, 2005).

Analysis of the trade balance of manufactured goods as a percentage of country GDP for the OECD7 countries, based on PPP weights, does not support this interpretation. Indeed, in the OECD7 the trade balance of manufactured goods over the period analysed is almost always positive and, although it showed a slight decline, its impact was limited (Figure 3). In the period analysed, average trade balance was no higher than $0.38 \%$ of GDP, ranging from a maximum of $0.36 \%$, in 1981 , to a minimum of $-0.02 \%$, in 1988 . More precisely, the negative trade balance of manufactured goods for the US, seems to be more or less counterbalanced by the positive balance for Germany and Japan.

\section{Insert Figure 3 about here}

We should emphasize that we are mainly interested in analysing the possible impact of delocalization practices on the dynamics of the shares of the value created and the labour employed in the production of manufactured goods, for the OECD7 as a whole. Therefore, trade balance patterns at country level are not directly relevant; what is important is that they tend to cancel out at the aggregate level. And this holds true also for the changes in the composition of imports and exports in manufactured goods, at least as far as these changes do not alter the aggregate shares. ${ }^{16}$

It would seem, therefore, that these changes that occurred also in the trade flows and patterns of the OECD7 are not able to invalidate what is emerging as an important result of the paper. To sum up, for the production of manufactured goods, we can reasonably conclude that,

16 Our conclusion is consistent with Rowthorn and Ramaswamy (1997). However, unlike their study, we do not control for the impact of North-South trade on deindustrialization, i.e. for the possibility that imports from less developed countries might be more labour intensive than exports from developed countries (Wood, 1994). Nevertheless, it should be noted that, although Rowthorn and Ramaswamy (1997) find no evidence of such an impact, theirs is a sector level analysis and the outcome could be different at subsystem level. On the role of deindustrialization in offsetting a worsening in British manufacturing trade see Rowthorn and Coutts (2004). 
although these production processes are undoubtedly crucial in economic systems, there is an evident decline in terms of contribution to labour employment and value creation. Thus, deindustrialization might be regarded as a general tendency characterizing developed economies in the retained period.

\subsection{The other side of the coin: tertiarization}

In terms of tertiarization, from the 1980s to the middle 1990s, the share of services of the OECD7 increased at a higher rate at subsystem than at sectoral level, in terms both of hours worked (9.34 vs 8 ) and value added (10.44 vs 8.94) (Tables 3 and 4). As suggested by the relative share in the corresponding subsystems, this can be related to the increased integration of market services in both market and non-market services (Tables 5 and 6).

The large increase in the share of market services in the non-market service subsystem from the early to the mid 1990s is particularly remarkable, both in terms of hours worked (3.22 percentage points) and value added (3.61 percentage points) (Tables 5(c) and 6(b)). As noted earlier, this could be related to the increased use of contracting-out by the public sector in this period. ${ }^{17}$

More generally, the interplay between market and non-market services induced by outsourcing practices has increased the 'sensitivity' of input-output data to intermediate inputs of services for the provision of public sector services. What was previously a nonmarket service intended for intermediate uses, and thus recorded in the input-output tables as final demand, has been transformed by outsourcing into a market service, and thus is classed as an

17 Although this occurred to different extents in different countries of the OECD7, suggesting a certain role of the public sector in driving the process, disaggregated data (available from the authors on request) show that, with the notable exception of Japan, the share of market service employment in the non-market subsystem has increased in each of the 7 countries, and especially from the late 1980s to the mid 1990s. This applies particularly to the UK, where the increase was almost 13 percentage points over the period. There were remarkable increases also for Canada ( 9.98 points) and Germany (8.71 points). In the case of the US, the pace of this integration increase is more stable and distributed along the period. This seems to support the idea that contracting-out practices by the public sector in the US are longer established, going back to at least the early 1980s (Domberger, 1998). 
intermediate input. This could be related to the observed high growth in the non-market service subsystem share with respect to the relative sectoral share, in terms mainly of value added. Over the whole period, the subsystem share of non-market services in the OECD7 increased by 4.78 percentage points in terms of hours worked, and by 3.73 points in terms of value added, while the corresponding changes in sectoral shares were 2.2 and 0.64 points (Tables 3 and 4).

\section{Conclusions}

The main result of this paper is somewhat at odds with the 'impure' deindustrialization accounts emerging in the context of the learning economy.

The weight of manufacturing in the OECD7 area decreased from the early 1980s to the mid 1990s, in the sense of less hours being worked and less value created in the production of manufactured goods in the 1990 s than in the early 1980 s. In the paper, we took a simple shareaccounting perspective and controlled for a number of 'impure' interpretations of deindustrialization, which tend to relegate it to a possibly 'lighter' industrialization era - either intensive of producer services or complementary to ICT services. However, our results show that these latter interpretations cannot fully account for the reduced weight of the OECD7 manufacturing sector and especially the manufacturing subsystem.

Although the nature of our application does not allow us to establish rigorous causal relationships, we consider that we have enough elements to conclude that the DT hypothesis is not dead. Rather than a simple re-organization of the manufacturing subsystem - as in Momigliano and Siniscalco's (1982a, 1986b, 1986a) study of Italy in the 1970s and 1980s - the OECD7 appears to be a less manufacturingbased global economy (though not necessarily a less material one). ${ }^{18}$

This 'actual' deindustrialization appears to be accompanied by an 'actual' tertiarization process, although a rather special one. The role of services has both increased, and possibly changed. The increasing integration of market services in non-market service subsystem would suggest a re-organization of production, in both the private and public

18 As a consequence of differential productivity growth, an increase in physical output (i.e. a more 'material' economy) might emerge even with the decrease in the value and employment of manufacturing due to deindustrialization. We are indebted to one of the two referees for suggesting this point. 
sectors.

This is an extremely important result, which the shift from a sectoral to a subsystem level analysis and a change from a national to a global perspective has enabled. The $\mathbf{B}$ operator is invaluable for taking into account the complexity of the relationships among the sectors of an economic system. Although our study contradicts Momigliano and Siniscalco's conclusions for Italy, their work, although more than 20 years old, is still worth reading! 


\section{References}

Andersen, B. and M. Corley (2002). The theoretical, conceptual and empirical impact of the service economy: A critical review. Paper presented at the DRUID Summer Conference on 'Industrial Dynamics of the New and Old Economy - who is embracing whom?' Copenhagen 6-8 June 2002.

Baranzini, M. and R. Scazzieri (1990). Economic structure: Analytical perspectives. In M. Baranzini and R. Scazzieri (Eds.), The Economic Theory of Structure and Change, Chapter IX, pp. 227333. Cambridge: Cambridge University Press.

Baumol, W. J. (1967). Macroeconomics of unbalanced growth: The anatomy of urban crisis. The American Economic Review 57(3), 415-426.

Baumol, W.J., Blackman, S.A.B. and E.N. Wolff (1989). Productivity and American leadership. The long view, Cambridge, MA: MIT Press.

Clark, C. (1940). The Conditions of Economic Progress. London: MacMillan \& Co Ltd.

Clark, C. (1957). The Conditions of Economic Progress ( $3^{\text {rd }}$ ed.). London: MacMillan \& Co Ltd.

Daniels, P. W. (2004). Reflections on the 'old' economy, 'new' economy, and services. Growth and Change 35(2), 115-138.

De Juan, O. and E. Febrero (2000). Measuring productivity from vertically integrated sectors. Economic Systems Research 12(1), 65-82.

Di Pilat, D. (2003). ICT and Economic Growth: Evidence from OECD Countries, Industries and Firms. Paris: OECD.

Dietrich, M. (1999). Explaining economic restructuring: an inputoutput analysis of organisational change in the European Union. International Review of Applied Economics 13(2), 219-240.

Domberger, S. (1998). The Contracting Organization. A Strategic Guide to Outsourcing. Oxford: Oxford University Press.

Foray, D. (2000). L'économie de la Connaissance. Paris: La Découverte.

Fuchs, V. R. (1964). Productivity trends in the goods and service sectors, 1929-61: A preliminary survey. Occasional paper 89, National Bureau of Economic Research, New York.

Fuchs, V. R. (1965). The growing importance of the service industries. 
The Journal of Business 38(4), 344-373.

Georgescu-Roegen, N. (1971). The Entropy Law and the Economic Process. Cambridge: Harvard University Press.

Gershuny, J. (1978). After Industrial Society: The Emerging SelfService Economy. Atlantic Highlands, N.J.: Humanities Press.

Gossling, W. (1972). Productivity Trends in a Sectoral MacroEconomic Model. London: Input-Output Publishing.

Greenfield, H. I. (1966). Manpower and the Growth of Producer Services. New York: Columbia University Press.

Gupta, S. and I. Steedman (1971). An input-output study of labour productivity in UK. Oxford Bulletin of Economics and Statistics $33,21-34$.

Jones, R. W. and H. Kierzkowski (1990). The role of services in production and international trade: A theoretical framework. In R. W. Jones and A. O. Krueger (Eds.), The Political Economy of International Trade: Essays in Honor of Robert E. Baldwin, pp. 31-48. Cambridge, MA: Blackwell.

Kuznets, S. (1957, July). Quantitative aspects of the economic growth of nations. Economic Development and Cultural Change. Supplement.

McCarthy, I. and A. Anagnostou (2004). The impact of outsourcing on the transaction costs and boundaries of manufacturing. International Journal of Production Economics 88, 61-71.

Milberg, W. S. (1991). Structural change and international competitiveness in Canada: an alternative approach. International Review of Applied Economics 5, 77-93.

Momigliano, F. and D. Siniscalco (1982a). The growth of service employment: a reappraisal. BNL Quarterly Review 142, 269-306.

Momigliano, F. and D. Siniscalco (1982b). Note in tema di terziarizzazione e deindustrializzazione. Moneta e Credito 138, $143-181$.

Momigliano, F. and D. Siniscalco (1986a). Ancora sull'integrazione dei servizi nel sistema produttivo: una nota. In L. L. Pasinetti (Ed.), Mutamenti Strutturali del Sistema Produttivo, pp. 115-126. Bologna: Il Mulino.

Momigliano, F. and D. Siniscalco (1986b). Mutamenti nella struttura del sistema produttivo e integrazione fra industria e servizi. In L. L. Pasinetti (Ed.), Mutamenti Strutturali del Sistema Produttivo, pp. 13-60. Bologna: Il Mulino.

Montresor, S. and Vittucci Marzetti, G. (2007). Outsourcing and 
structural change. What can input-output analysis say about it? Economia Politica XXIV(1), 43-78.

Panethimitakis, A. J. (1993). Direct versus total labour productivity in Greek manufacturing: 1958-1986. Economic Systems Research 5, 79-93.

Pasinetti, L. L. (1973). The notion of vertical integration in economic analysis. Metroeconomica 1, 1-29.

Pasinetti, L. L. (1993). Structural Economic Dynamics. A Theory of the Economic Consequences of Human Learning. Cambridge: Cambridge University Press.

Postner, H. H. (1990). The contracting-out problem in service sector analysis: Choice of statistical unit. Review of Income and Wealth 36(2), 177-186.

Rampa, G. (1982). Commento a Momigliano e Siniscalco. Moneta e Credito 139, 475-479.

Rostow, W. W. (1959). The stages of economic growth. The Economic History Review XII(1), 1-16.

Rostow, W. W. (1990). The Stages of Economic Growth: A NonCommunist Manifesto ( ${ }^{\text {rd }}$ ed.). Cambridge: Cambridge University Press.

Rowthorn, R. and K. Coutts (2004). De-industrialization and the balance of payments in advanced economies. Cambridge Journal of Economics 28(5), 767-790.

Rowthorn, R. and R. Ramaswamy (1997). Deindustrialization: Causes and implications. Working Paper 97/42, International Monetary Found.

Rowthorn, R. and R. Ramaswamy (1999). Growth, trade and deindustrialization. IMF Staff Papers 46(1), 18-41.

Rowthorn, R. and J.R. Wells (1987). De-industrialization and foreign trade. Cambridge: Cambridge University Press.

Scazzieri, R. (1990). Vertical integration in economic theory. Journal of Post Keynesian Economics 13(1), 20-46.

Schettkat, R. (2007, July). The astonishing regularity of service employment expansion. Metroeconomica 58(3), 413-435.

Schettkat, R. and L. Yocarini (2006, June). The shift to services employment: A review of the literature. Structural Change and Economic Dynamics 17(2), 127-147.

Sherwood, M. K. (1994, March). Difficulties in the measurement of services. Monthly Labor Review 117(3), 11-19.

Spencer, B. J. (2005). International outsourcing and incomplete 
contracts. Working Paper 11418, National Bureau of Economic Research.

Sraffa, P. (1960). Production of Commodities by Means of Commodities. Cambridge: Cambridge University Press.

Stanback, T. M. (1979). Understanding the Service Economy. Baltimora: Johns Hopkins University Press.

Stanback, T. M. (1981). Services: The New Economy. Totowa, NJ: Littlefield Adams.

Stigler, G. J. (1956). Trend of Employment in the Service Industries. Princeton: Princeton University Press.

Tomlinson, M. (2000). The contribution of knowledge-intensive services to the manufacturing industry. In M. Boden and I. Miles (Eds.), Services and the Knowledge-based Economy, pp. 36-48. London: Continuum.

Wolff, E. (1985). Industrial composition, interindustry effects, and the U.S. productivity slowdown. Review of Economics and Statistics 67, 268-277.

Wood, A. (1994). North-South Trade, Employment and Inequality. Oxford: Clarendon Press. 


\section{A. Input-Output Data Coverage}

\begin{tabular}{lcccc}
\hline Country & \multicolumn{4}{c}{ Input-Output Tables } \\
\cline { 2 - 5 } & early '80s & mid-'80s & early '90s & mid-'90s \\
\hline Canada & 1981 & 1986 & 1990 & 1997 \\
Denmark & 1980 & 1985 & 1990 & 1997 \\
France & 1980 & 1985 & 1990 & 1995 \\
Germany & 1986 & 1988 & 1990 & 1995 \\
Japan & 1980 & 1985 & 1990 & 1995 \\
United Kingdom & 1979 & 1984 & 1990 & 1998 \\
United States & 1982 & 1985 & 1990 & 1997 \\
\hline
\end{tabular}




\section{Tables and Figures}

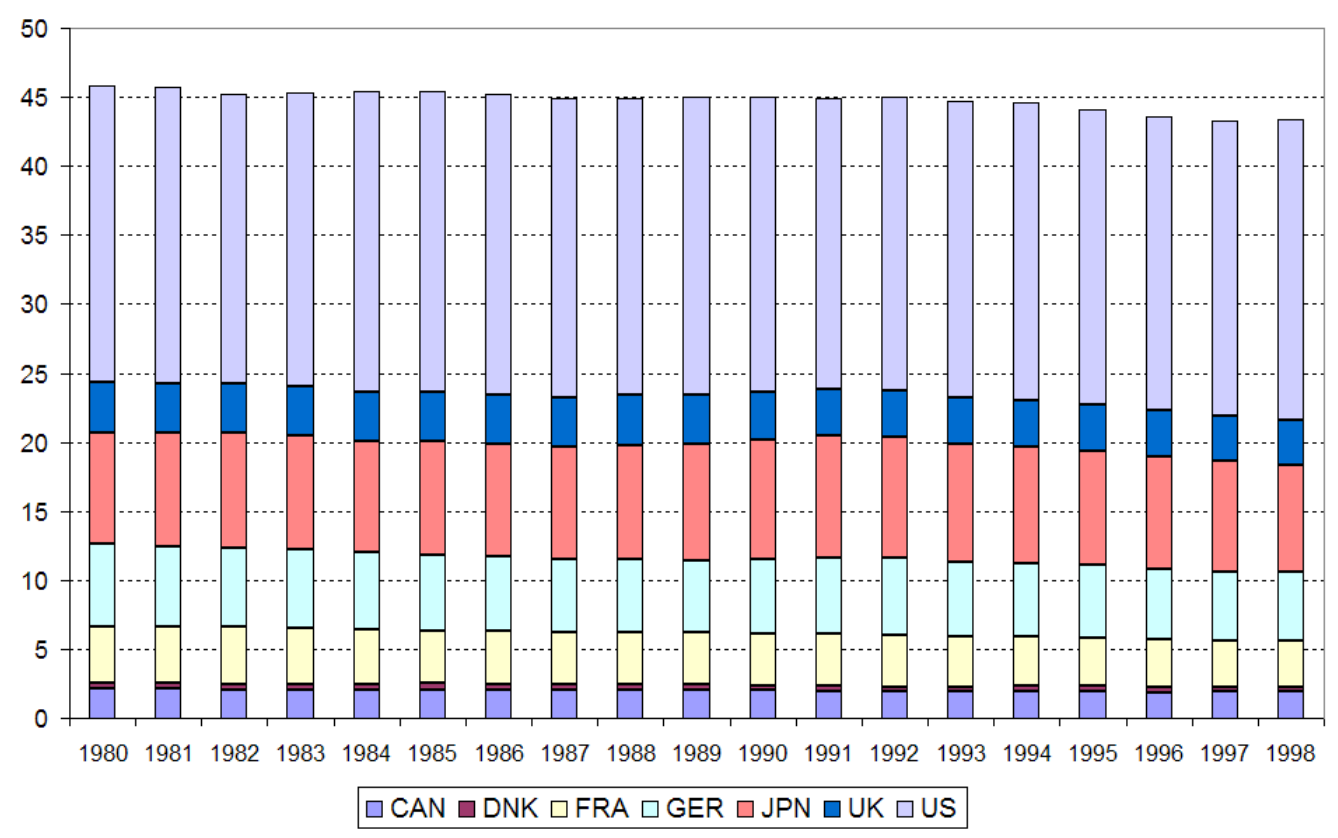

Source: World Economic Outlook Database, 2005.

Figure 1: OECD7 share of world GDP at PPP 


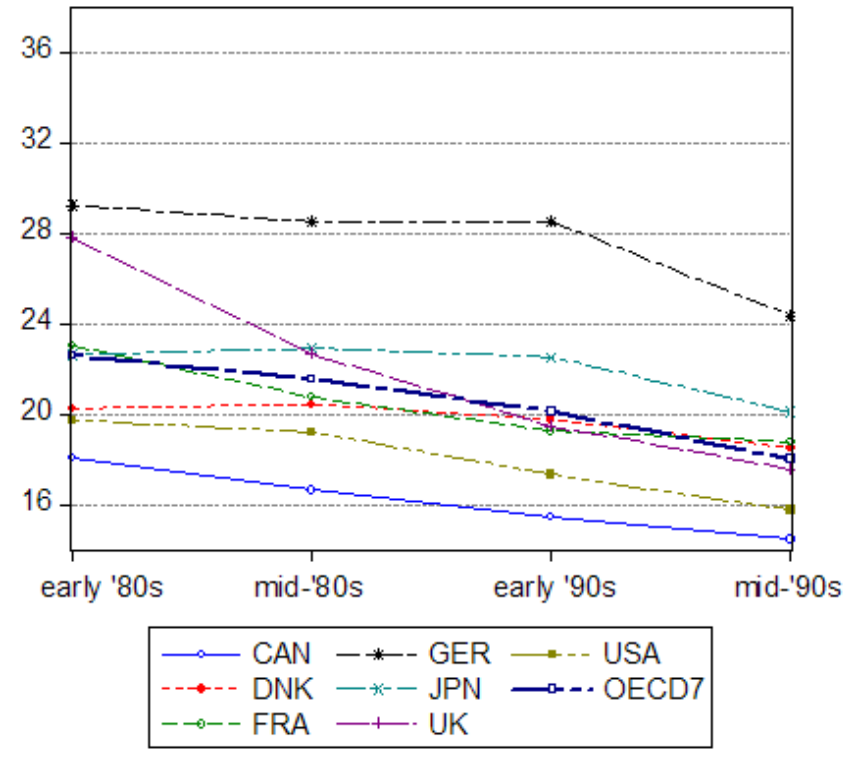

(a) Sector

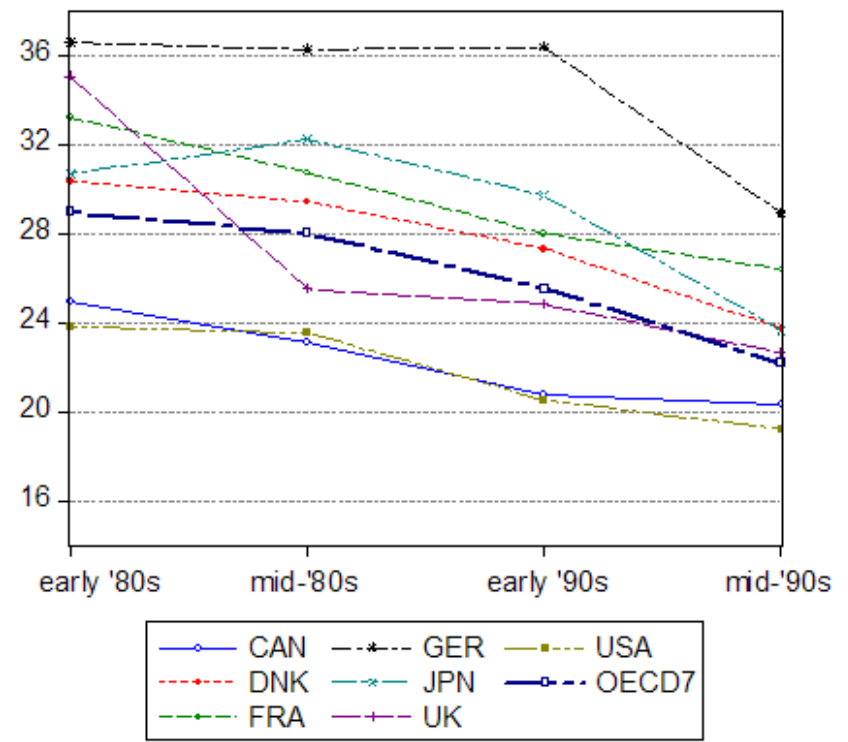

(b) Subsystem

Figure 2 - Shares of total hours worked for manufacturing 


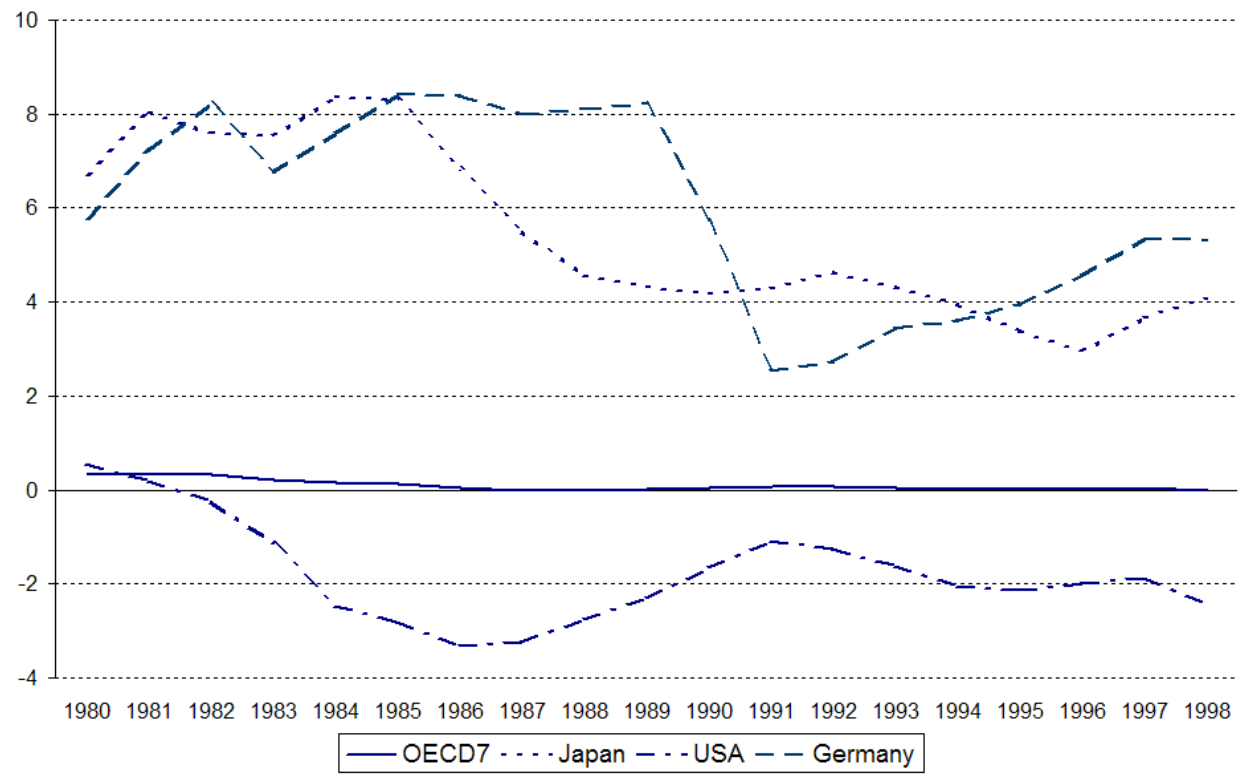

Source: OECD STAN Database (2004) and World Economic Outlook Database (2005).

Figure 3: Trade balance of manufactured goods in OECD7 as a percentage of GDP (PPP weights) 
Table 1: International trade integration of the OECD7

\begin{tabular}{llllllllll}
\hline & 1990 & 1991 & 1992 & 1993 & 1994 & 1995 & 1996 & 1997 & 1998 \\
\hline Manufacturing $^{\mathrm{a}}$ & 46.1 & 45.4 & 44.6 & 45.3 & 45.1 & 43.9 & 43.3 & 43.8 & 44.5 \\
Total $^{\mathrm{b}}$ & 44.2 & 43.5 & 43.0 & 43.6 & 43.6 & 42.5 & 42.0 & 42.6 & 43.6 \\
\hline
\end{tabular}

a $\quad \sum_{i=1}^{7} \frac{\sum_{j=1}^{7}\left(X_{i j}^{m}+M_{i j}^{m}\right)}{\sum_{i=1 j}^{7} \sum_{i j}\left(X_{i j}^{m}+M_{i j}^{m}\right)}$, where $X_{i j}^{m}$ are exports of manufactured goods from country $i$ to $j, M_{i j}{ }^{m}$ are imports of manufactured goods from country $j$ to $i$, and the countries are ordered in such a way that the first seven belong to the OECD7.

b $\sum_{i=1}^{7} \frac{\sum_{j=1}^{7}\left(X_{i j}+M_{i j}\right)}{\sum_{i=1}^{7} \sum\left(X_{i j}+M_{i j}\right)}$, where $X_{i j}$ are exports from country $i$ to $j, M_{i j}$ are imports from country $j$ to $i$, and the countries are ordered in such a way that the first seven belong to the OECD7.

Source: OECD STAN Bilateral Trade Database, 2006. 
Table 2: Hours worked by sector/subsystem in the OECD7

\begin{tabular}{|c|c|c|c|c|c|}
\hline & & early' 80 s & mid-' $80 \mathrm{~s}$ & early '90s & mid-'90s \\
\hline \multirow[t]{2}{*}{ Primary } & Sector & $37,700,172$ & $\begin{array}{r}33,723,454 \\
(-3,976,719)\end{array}$ & $\begin{array}{r}29,307,863 \\
(-4,415,591)\end{array}$ & $\begin{array}{r}24,629,501 \\
(-4,678,362)\end{array}$ \\
\hline & Subsystem & $13,895,862$ & $\begin{array}{r}12,611,489 \\
(-1,284,373)\end{array}$ & $\begin{array}{r}11,793,032 \\
(-818,457)\end{array}$ & $\begin{array}{r}10,035,300 \\
(-1,757,732)\end{array}$ \\
\hline \multirow[t]{2}{*}{ Manufacturing } & Sector & $106,179,748$ & $\begin{array}{r}104,728,629 \\
(-1,451,119)\end{array}$ & $\begin{array}{r}104,452,384 \\
(-276,244)\end{array}$ & $\begin{array}{r}97,238,631 \\
(-7,213,754)\end{array}$ \\
\hline & Subsystem & $136,112,879$ & $\begin{array}{r}136,122,350 \\
(9,470)\end{array}$ & $\begin{array}{r}132,649,492 \\
(-3,472,858)\end{array}$ & $\begin{array}{r}119,782,561 \\
(-12,866,931)\end{array}$ \\
\hline \multirow[t]{2}{*}{ Public Utilities } & Sector & $4,242,153$ & $\begin{array}{r}4,332,810 \\
(90,656)\end{array}$ & $\begin{array}{r}4,472,372 \\
(139,562)\end{array}$ & $\begin{array}{r}4,207,845 \\
(-264,527)\end{array}$ \\
\hline & Subsystem & $4,681,344$ & $\begin{array}{r}4,328,551 \\
(-352,793)\end{array}$ & $\begin{array}{r}4,631,808 \\
(303,257)\end{array}$ & $\begin{array}{r}4,573,702 \\
(-58,107)\end{array}$ \\
\hline \multirow[t]{2}{*}{ Construction } & Sector & $36,238,076$ & $\begin{array}{r}36,363,778 \\
(125,702)\end{array}$ & $\begin{array}{r}40,420,758 \\
(4,056,980)\end{array}$ & $\begin{array}{r}42,798,288 \\
(2,377,530)\end{array}$ \\
\hline & Subsystem & $59,049,399$ & $\begin{array}{r}57,049,589 \\
(-1,999,811)\end{array}$ & $\begin{array}{r}61,710,582 \\
(4,660,994)\end{array}$ & $\begin{array}{r}61,041,902 \\
(-668,680)\end{array}$ \\
\hline \multirow[t]{2}{*}{ Market services } & Sector & $179,101,746$ & $\begin{array}{r}195,239,286 \\
(16,137,539)\end{array}$ & $\begin{array}{r}214,688,898 \\
(19,449,612)\end{array}$ & $\begin{array}{r}237,355,549 \\
(22,666,651)\end{array}$ \\
\hline & Subsystem & $147,735,188$ & $\begin{array}{r}164,696,060 \\
(16,960,871)\end{array}$ & $\begin{array}{r}176,995,039 \\
(12,298,980)\end{array}$ & $\begin{array}{r}194,607,392 \\
(17,612,353)\end{array}$ \\
\hline \multirow[t]{2}{*}{ Non market services } & Sector & $105,924,143$ & $\begin{array}{r}11,075,352 \\
(5,151,209)\end{array}$ & $\begin{array}{r}125,590,539 \\
(14,515,187)\end{array}$ & $\begin{array}{r}133,760,729 \\
(8,170,190)\end{array}$ \\
\hline & Subsystem & $107,911,366$ & $\begin{array}{r}110,655,270 \\
(2,743,904) \\
\end{array}$ & $\begin{array}{r}131,152,861 \\
(20,497,591) \\
\end{array}$ & $\begin{array}{r}149,949,687 \\
(18,796,826) \\
\end{array}$ \\
\hline Total & & $469,386,039$ & $\begin{array}{r}485,463,307 \\
(16,077,268)\end{array}$ & $\begin{array}{r}18,932,814 \\
(33,469,506) \\
\end{array}$ & $\begin{array}{r}539,990,543 \\
(21,057,730) \\
\end{array}$ \\
\hline
\end{tabular}

Source: OECD I-O Database and 60-Industries GGDC Database. 
Table 3: Sectoral and subsystem shares of the OECD7 total economy (hours worked)

\begin{tabular}{llrrrr}
\hline & & early '80s & mid-'80s & early '90s & mid-'90s \\
\hline Primary & Sector & 8.03 & 6.95 & 5.65 & 4.56 \\
& & & $(-1.09)$ & $(-1.30)$ & $(-1.09)$ \\
& Subsystem & 2.96 & 2.60 & 2.27 & 1.86 \\
Manufacturing & & & $(-0.36)$ & $(-0.33)$ & $(-0.41)$ \\
& Sector & 22.62 & 21.57 & 20.13 & 18.01 \\
& & & $(-1.05)$ & $(-1.44)$ & $(-2.12)$ \\
& Subsystem & 29.00 & 28.04 & 25.56 & 22.18 \\
Public Utilities & & & $(-0.96)$ & $(-2.48)$ & $(-3.38)$ \\
& Sector & 0.90 & 0.89 & 0.86 & 0.78 \\
& & & $(-0.01)$ & $(-0.03)$ & $(-0.08)$ \\
& Subsystem & 1.00 & 0.89 & 0.89 & 0.85 \\
Construction & & & $(-0.11)$ & $(0.00)$ & $(-0.05)$ \\
& Sector & 7.72 & 7.49 & 7.79 & 7.93 \\
& & & $(-0.23)$ & $(0.30)$ & $(0.14)$ \\
& Subsystem & 12.58 & 11.75 & 11.89 & 11.30 \\
Market services & & & $(-0.83)$ & $(0.14)$ & $(-0.59)$ \\
& Sector & 38.16 & 40.22 & 41.37 & 43.96 \\
& & & $(2.06)$ & $(1.15)$ & $(2.58)$ \\
& Subsystem & 31.47 & 33.93 & 34.11 & 36.04 \\
\multirow{2}{*}{ Non market services } & & & $(2.45)$ & $(0.18)$ & $(1.93)$ \\
& Sector & 22.57 & 22.88 & 24.20 & 24.77 \\
& & & $(0.31)$ & $(1.32)$ & $(0.57)$ \\
& Subsystem & 22.99 & 22.79 & 25.27 & 27.77 \\
& & & $(-0.20)$ & $(2.48)$ & $(2.50)$ \\
\hline
\end{tabular}

Source: OECD I-O Database and 60-Industries GGDC Database. 
Table 4: Sectoral and subsystem shares of the OECD7 total economy (value added, PPP weights)

\begin{tabular}{|c|c|c|c|c|c|}
\hline & & early '80s & mid-' $80 \mathrm{~s}$ & early '90s & mid-'90s \\
\hline \multirow[t]{2}{*}{ Primary } & Sector & 5.58 & $\begin{array}{r}4.76 \\
(-0.82)\end{array}$ & $\begin{array}{r}3.38 \\
(-1.38)\end{array}$ & $\begin{array}{r}2.66 \\
(-0.72)\end{array}$ \\
\hline & Subsystem & 2.09 & $\begin{array}{r}1.96 \\
(-0.13)\end{array}$ & $\begin{array}{r}1.61 \\
(-0.35)\end{array}$ & $\begin{array}{r}1.30 \\
(-0.31)\end{array}$ \\
\hline \multirow[t]{2}{*}{ Manufacturing } & Sector & 24.14 & $\begin{array}{l}23.14 \\
(-0.99)\end{array}$ & $\begin{array}{l}22.16 \\
(-0.98)\end{array}$ & $\begin{array}{l}19.56 \\
(-2.61)\end{array}$ \\
\hline & Subsystem & 29.57 & $\begin{array}{l}28.82 \\
(-0.75)\end{array}$ & $\begin{array}{l}26.98 \\
(-1.84)\end{array}$ & $\begin{array}{l}22.86 \\
(-4.12)\end{array}$ \\
\hline \multirow[t]{2}{*}{ Public Utilities } & Sector & 2.51 & $\begin{array}{r}3.03 \\
(0.52)\end{array}$ & $\begin{array}{r}2.42 \\
(-0.61)\end{array}$ & $\begin{array}{r}2.27 \\
(-0.15)\end{array}$ \\
\hline & Subsystem & 2.04 & $\begin{array}{l}2.08 \\
(0.05)\end{array}$ & $\begin{array}{r}1.79 \\
(-0.29)\end{array}$ & $\begin{array}{r}1.63 \\
(-0.17)\end{array}$ \\
\hline \multirow[t]{2}{*}{ Construction } & Sector & 7.06 & $\begin{array}{r}6.00 \\
(-1.06)\end{array}$ & $\begin{array}{c}6.61 \\
(0.61)\end{array}$ & $\begin{array}{r}5.86 \\
(-0.75)\end{array}$ \\
\hline & Subsystem & 12.01 & $\begin{array}{l}10.68 \\
(-1.32)\end{array}$ & $\begin{array}{r}11.01 \\
(0.33)\end{array}$ & $\begin{array}{r}9.47 \\
(-1.54)\end{array}$ \\
\hline \multirow[t]{2}{*}{ Market services } & Sector & 40.90 & $\begin{array}{r}42.62 \\
(1.72)\end{array}$ & $\begin{array}{r}45.36 \\
(2.74)\end{array}$ & $\begin{array}{r}49.21 \\
(3.85)\end{array}$ \\
\hline & Subsystem & 33.06 & $\begin{array}{r}35.11 \\
(2.05)\end{array}$ & $\begin{array}{r}36.26 \\
(1.14)\end{array}$ & $\begin{array}{r}39.77 \\
(3.51)\end{array}$ \\
\hline \multirow[t]{2}{*}{ Non market services } & Sector & 19.80 & $\begin{array}{r}20.44 \\
(0.64)\end{array}$ & $\begin{array}{l}20.07 \\
(-0.38)\end{array}$ & $\begin{array}{r}20.44 \\
(0.37)\end{array}$ \\
\hline & Subsystem & 21.24 & $\begin{array}{r}21.34 \\
(0.10)\end{array}$ & $\begin{array}{r}22.35 \\
(1.01)\end{array}$ & $\begin{array}{r}24.97 \\
(2.62)\end{array}$ \\
\hline
\end{tabular}

Source: World Economic Outlook Database and OECD I-O Database. 
Table 5: Market services integration in the production system in the OECD7 (hours worked)

(a) Market services employment in subsystems (absolute values)

\begin{tabular}{lrrrr}
\hline Subsystem & early '80s & mid-'80s & early'90s & mid-'90s \\
\hline Primary & $1,351,668$ & $1,336,592$ & $1,367,255$ & $1,421,716$ \\
& & $(-15,077)$ & $(30,663)$ & $(54,461)$ \\
Manufacturing & $27,036,126$ & $28,351,675$ & $29,977,849$ & $31,049,241$ \\
& & $(1,315,548)$ & $(1,626,174)$ & $(1,071,391)$ \\
Public Utilities & $1,056,993$ & 973,230 & $1,196,389$ & $1,316,193$ \\
& & $(-83,763)$ & $(223,159)$ & $(119,804)$ \\
Construction & $11,872,229$ & $10,824,500$ & $13,084,453$ & $12,962,725$ \\
& & $(-1,047,729)$ & $(2,259,954)$ & $(-121,728)$ \\
Market services & $128,922,953$ & $144,538,685$ & $158,133,652$ & $173,288,046$ \\
& & $(15,615,732)$ & $(13,594,967)$ & $(15,154,394)$ \\
Non market services & $8,861,777$ & $9,214,605$ & $10,929,299$ & $17,317,628$ \\
& & $(352,827)$ & $(1,714,695)$ & $(6,388,329)$ \\
\hline
\end{tabular}

(b) Market services integration into subsystems (percentage values)

\begin{tabular}{lrrrr}
\hline Subsystem & early '80s & mid-'80s & early '90s & mid-'90s \\
\hline Primary & 0.8 & 0.7 & 0.6 & 0.6 \\
Manufacturing & 15.1 & 14.5 & 14.0 & 13.1 \\
Public Utilities & 0.6 & 0.5 & 0.6 & 0.6 \\
Construction & 6.6 & 5.5 & 6.1 & 5.5 \\
Market services & 72.0 & 74.0 & 73.7 & 73.0 \\
Non market services & 4.9 & 4.7 & 5.1 & 7.3 \\
\hline Total & 100.0 & 100.0 & 100.0 & 100.0 \\
\hline
\end{tabular}

(c) Share of market services employment in subsystems (percentage values)

\begin{tabular}{lrrrr}
\hline Subsystem & early '80s & mid-'80s & early '90s & mid-'90s \\
\hline Primary & 9.7 & 10.6 & 11.6 & 14.2 \\
Manufacturing & 19.9 & 20.8 & 22.6 & 25.9 \\
Public Utilities & 22.6 & 22.5 & 25.8 & 28.8 \\
Construction & 20.1 & 19.0 & 21.2 & 21.2 \\
Market services & 87.3 & 87.8 & 89.3 & 89.0 \\
Non market services & 8.2 & 8.3 & 8.3 & 11.5 \\
\hline
\end{tabular}

Source: OECD I-O Database and 60-Industries GGDC Database. 
Table 6: Market services integration in the production system in the OECD7 (value added, PPP weights)

(a) Market services integration into subsystems (percentage values)

\begin{tabular}{lrrrr}
\hline Subsystem & early '80s & mid-'80s & early '90s & mid-'90s \\
\hline Primary & 0.86 & 0.77 & 0.70 & 0.60 \\
Manufacturing & 15.58 & 15.05 & 14.68 & 12.49 \\
Public Utilities & 0.72 & 0.59 & 0.65 & 0.58 \\
Construction & 6.53 & 5.83 & 6.25 & 5.23 \\
Market services & 71.09 & 72.47 & 71.89 & 73.23 \\
Non market services & 5.22 & 5.29 & 5.82 & 7.86 \\
\hline Total & 100.0 & 100.0 & 100.0 & 100.0 \\
\hline
\end{tabular}

(b) Share of market services in subsystems (percentage values)

\begin{tabular}{lrrrr}
\hline Subsystem & early '80s & mid-'80s & early '90s & mid-'90s \\
\hline Primary & 17.52 & 18.36 & 19.95 & 23.43 \\
Manufacturing & 21.54 & 22.01 & 24.21 & 26.60 \\
Public Utilities & 15.10 & 12.49 & 16.70 & 17.80 \\
Construction & 22.17 & 23.33 & 25.53 & 27.03 \\
Market services & 87.84 & 87.96 & 90.14 & 90.83 \\
Non market services & 10.28 & 10.84 & 11.86 & 15.47 \\
\hline
\end{tabular}

Source: World Economic Outlook Database and OECD I-O Database. 
Table 7: Manufacturing integration in the production system in the OECD7 (hours worked)

(a) Manufacturing employment in subsystems (absolute values)

\begin{tabular}{lrrrr}
\hline Subsystem & early '80s & mid-'80s & early '90s & mid-'90s \\
\hline Primary & 795,797 & 779,164 & 667,844 & 541,867 \\
& & $(-16,633)$ & $(-111,320)$ & $(-125,977)$ \\
Manufacturing & $81,971,395$ & $81,945,607$ & $80,672,788$ & $71,757,410$ \\
& & $(-25,788)$ & $(-1,272,818)$ & $(-8,915,378)$ \\
Public Utilities & 498,204 & 401,015 & 409,070 & 359,813 \\
& & $(-97,189)$ & $(8,055)$ & $(-49,257)$ \\
Construction & $10,507,969$ & $9,596,263$ & $10,138,078$ & $9,846,569$ \\
& & $(-911,706)$ & $(541,815)$ & $(-291,509)$ \\
Market services & $7,446,497$ & $7,327,251$ & $7,699,889$ & $8,862,190$ \\
& & $(-119,245)$ & $(372,638)$ & $(1,162,301)$ \\
Non market services & $4,959,887$ & $4,679,328$ & $4,864,715$ & $5,870,781$ \\
& & $(-280,559)$ & $(185,386)$ & $(1,006,067)$ \\
\hline
\end{tabular}

(b) Manufacturing sectors integration into subsystems (percentage values)

\begin{tabular}{lrrrr}
\hline Subsystem & early '80s & mid-'80s & early '90s & mid-'90s \\
\hline Primary & 0.7 & 0.7 & 0.6 & 0.6 \\
Manufacturing & 77.2 & 78.2 & 77.2 & 73.8 \\
Public Utilities & 0.5 & 0.4 & 0.4 & 0.4 \\
Construction & 9.9 & 9.2 & 9.7 & 10.1 \\
Market services & 7.0 & 7.0 & 7.4 & 9.1 \\
Non market services & 4.7 & 4.5 & 4.7 & 6.0 \\
\hline Total & 100.0 & 100.0 & 100.0 & 100.0 \\
\hline
\end{tabular}

(c) Share of manufacturing employment in subsystems (percentage values)

\begin{tabular}{lrrrr}
\hline Subsystem & early '80s & mid-'80s & early '90s & mid-'90s \\
\hline Primary & 5.7 & 6.2 & 5.7 & 5.4 \\
Manufacturing & 60.2 & 60.2 & 60.8 & 59.9 \\
Public Utilities & 10.6 & 9.3 & 8.8 & 7.9 \\
Construction & 17.8 & 16.8 & 16.4 & 16.1 \\
Market services & 5.0 & 4.4 & 4.4 & 4.6 \\
Non market services & 4.6 & 4.2 & 3.7 & 3.9 \\
\hline
\end{tabular}

Source: OECD I-O Database and 60-Industries GGDC Database. 
Table 8: Manufacturing integration in the production system in the OECD7 (value added, PPP weights)

(a) Manufacturing sectors integration into subsystems (percentage values)

\begin{tabular}{lrrrr}
\hline Subsystem & early '80s & mid-'80s & early '90s & mid-'90s \\
\hline Primary & 0.89 & 0.86 & 0.76 & 0.64 \\
Manufacturing & 77.16 & 78.32 & 77.69 & 74.70 \\
Public Utilities & 0.54 & 0.50 & 0.47 & 0.40 \\
Construction & 9.12 & 8.61 & 8.71 & 8.50 \\
Market services & 7.35 & 7.17 & 7.59 & 9.54 \\
Non market services & 4.94 & 4.54 & 4.78 & 6.23 \\
\hline Total & 100.0 & 100.0 & 100.0 & 100.0 \\
\hline
\end{tabular}

(b) Share of manufacturing in subsystems (percentage values)

\begin{tabular}{lrrrr}
\hline Subsystem & early '80s & mid-'80s & early '90s & mid-'90s \\
\hline Primary & 11.03 & 10.81 & 10.81 & 9.92 \\
Manufacturing & 62.82 & 62.83 & 63.97 & 64.00 \\
Public Utilities & 6.42 & 5.52 & 5.76 & 4.78 \\
Construction & 17.98 & 18.33 & 17.34 & 17.51 \\
Market services & 5.31 & 4.72 & 4.62 & 4.58 \\
Non market services & 5.53 & 4.99 & 4.61 & 5.03 \\
\hline
\end{tabular}

Source: World Economic Outlook Database and OECD I-O Database. 